\title{
MARKETING AND INNOVATION - A RELATIONSHIP APPROACH
}

\author{
Rodica Boier \\ “Gheorghe Asachi” Technical University of Iaşi \\ Rodica_Boier@yahoo.com
}

\begin{abstract}
This paper deals with innovation from a relationship marketing perspective, the company's ability to maintain interactions with its stakeholders, to take advantage from the information achieved, and this way to create new products and generate loyalty through customer satisfaction. The analysis of innovation from a relationship establishment standpoint can only be viewed interdisciplinary at its core, with research and development, design, management, and marketing being symbiotically combined, with focus on stakeholders' involvement. The paper reviwes the most significat literature in the area. There is a two-way connection between relationship marketing and innovation. On one hand, the newly launched product, conceived together with the stakeholders, is likely to generate satisfaction and, hence, customer loyalty and retention, with all known positive consequences. On the other hand, the repeated satisfaction felt by the stakeholder encourages him to expect even more from the innovative organization in what concerns the successfully launched new products. This way, the effective stakeholder involvement in the value creation process provides a strong basis for further innovation.
\end{abstract}

\section{Keywords}

relationship marketing; innovation; new product development; stakeholders; innovation networks

\section{JEL Classification}

M31

\section{Introduction}

Many years ago already Peter Drucker asserted that marketing and innovation are considered to be the two basic functions of any business enterprise. The value created by the company should be customer-oriented, to generate both customer satisfaction and the expected customer relationship value. The paper deals with innovation from a relationship marketing (RM) perspective.

The rate of new product (NP) failure continues to be high despite the fact that innovation and marketing have become increasingly important tools for the companies' profitability, and the primary reason remains the still poor understanding of the complex nature of customer needs, values and behavior. Because, in the future, organizations will be more and more differentiated by their capability to successfully interact with their stakeholders, customers first, it will be valuable to analyse if companies really involve them in their new product development (NPD) process, how do they do this and what results it produces. In this respect, Bhalla urges for a real process of „,rethinking marketing and innovation” (2011, p. 123-143). 


\section{The relationship orientation in innovation. A literature review}

There is a growing body of literature that deals with innovation and RM. A relationships orientation in innovation reflects a company's ability to maintain interactions with its stakeholders, to take advantage from the information achieved, this way to create NPs and generate loyalty through customer satisfaction. In this context, the term „stakeholders” refers to the primary interested entities - consumers, customers, suppliers, employees, shareholders, regulators and the community, as well as the society at large (Hult et al., 2011). All of them can participate, through specific relationships, to the complex process of value co-creation, managed by the innovative organisation.

Innovation and NPD is an important issue in collaborative relationships between organizations. Heide and John (1990) investigated the determinants of joint action in alliances between buyers and sellers, one of those being the component testing/prototyping. The development of a business network that emerged when a NP was developed and tried together with customer organizations was also described by Anderson et al. (1994). Ramani and Kumar (2008) linked the RM with innovation at a higher level of generality and stated that RM „,is a process for developing innovation capability and providing a lasting competitive advantage” (p. 27). Lately, some authors have included ,innovativeness” along with other general RM constructs, as mutual trust, satisfaction, experience, loyalty, commitment etc., as reflected by a substantial inventory created by Agaryia and Singh (2011, p. 207-224).

When developing a NP, it is crucial to include the relational context analysis. In this respect, several researchers (Fang et al., 2008; Tuli et al., 2007; Franke, 2006; Lagrosen, 2005) have discussed methods and benefits of interacting with customers and other stakeholders, but the domain is still developing. Inspired from the context of industrial market, RM and innovation have been expanded more and more to the consumer markets as well.

There is a two-way connection between RM and innovation. On one hand, the newly launched product, conceived together with the stakeholders, is likely to generate satisfaction and, hence, customer loyalty and retention, with all known positive consequences. On the other hand, the repeated satisfaction felt by the stakeholder encourages him to expect even more from the innovative organization in what concerns the successfully launched NPs. This way, the effective stakeholder involvement in the value creation process provides a strong basis for further innovation.

It is critically important in innovation the approach in the broadest sense of MR customers but also other stakeholders involved. Similarly, there is to be considered the whole range of aggregation level in relationship interactions - actions, episodes, sequences, relationships, and partner base -, as hierarchical levels that range from a single individual exchange to the entire relationship portfolio of a company (Holmlund, 2004). On the other hand, as far as innovation in itself is concerned, it must be viewed in its broad complexity of forms, including practices, processes, and systems relating to products, services, IT, etc. In such perspective, the analysis of innovation from a relationship establishment standpoint can only be viewed interdisciplinarily at its core, with $\mathrm{R} \& \mathrm{D}$, design, management, and marketing being symbiotically combined, with focus on stakeholders involvement.

The RM practice in innovation can be found in a wide variety of circumstances, each characterized by corresponding particularities. This diversity can be attributed to the type of product (B2B or B2C), to the industry specifics, to the actual stage of the market evolution - emerging, mature or decreasing -, the level of technological novelty as dimension of technological uncertainty, to the status and role of the stakeholders in their role of relationship builders, to the NPD process status in which the relationship takes place, or to special issues like sustainable innovation, for profit 
and not-for-profit areas s.a. For instance, Athanassopoulos (2000) demonstrates that customer satisfaction is a function of innovation, but individual customers do not value product innovation as much as B2B customers. Or, Nambisan and Baron (2009) propose collaboration platforms for social innovations that require collaboration / relationships among diverse networks of nonprofits, government agencies, corporations, and private citizens.

All the variables that ensure the RM success can be found, with their specificity, in the management of the NP: commitment, trust, seller's customer orientation and empathy, experience and satisfaction, communication a.s.o. More specific, innovation-related benefits of the RM go from the improvement of customer focus, enhancement of customer knowledge and feedback and improvement of customer solutions, to the enablement of product customization and personalization and, this way, better customer attraction, conversion and retention or even winning-back lost customers (Richards and Jones, 2008; Spekman and Carraway, 2006; Tanner et al., 2005; Thomas et al., 2004; Thomas et al., 2004; Sabri, 2003; Zikmund et al., 2002; Verhoef, 2003; Sheth and Sharma, 2001; Winer, 2001, Sheth et al., 2000).

The mix of relationships, as seen by Gummesson (2008), also apply to the specific of innovation. Relationship innovation could appear through market relationships - the classic supplier-customer dyad, the supplier-customer-competitior triad and the physical distribution network -, but also through non-market relationship, with two levels - the mega relationships (platform for market relationships, concerned with the economy and society in general) -, and nano relationships (intraorgannizational relationships) (p. 38-39).

\section{Dimensions of the relational approach in innovation}

As overwhelmingly demonstrated, the most successful innovation and NPD efforts match a set o fully understood customer problems to a cost-competitive solution to those problems (Griffin et al., 2012; Rust et al., 2009). More and more these days, the stakeholders are attracted in the design process, where marketing and R\&D are fully integrated. During the NPD process, a complex set of relationship approaches develop between producer and stakeholders, especially the customers.

Interaction management in customer integrated innovation is an opportunity for companies to supply relational service to customer and to improve customer value and relationship quality (Sun et al., 2010, p. 56-57). But companies also need to assess how to best ensure their capability to enable the most fruitful atmosphere from a relationship building standpoint in order to source meaningful ideas from outside the company and even outside the industry, insights and knowledge from customers and end users, suppliers and competitors, universities, independent entrepreneurs, investors, inventors, scientists a.s.o. Besides the classical internal sources of the innovation value chain (Hansen and Birkinshaw, 2007), "cross-pollination” (Evans and Wolf, 2005; Eisenhardt and Galunic, 2000) and external sources (von Hippel, 2005; Kim and Mauborgne, 2004; Chesbrough, 2011 and 2008) have established themselves equally as viable solutions, both of them involving at the same time a large and also deep network of professional relationships. Perks and Moxey (2011) highlighted that high levels of product innovation activity primarily occur in companies leading and developing networks.

Because understanding customer needs driving product innovation is vital for NP developers, it is important for them to identify that dimensions of the relationship process able to make the organization more proactive. In a B2B setting, customer interactivity is conceptualized as a multidimensional construct consisting of bidirectional communications, participation, and joint problem solving during NPD projects (Bonner, 2010). In the same context, Ramani and Kumar (2008) studied the 
main components of such an interaction orientation as been the customer concept, the interaction response capacity, customer empowerment, and customer value management.

Interesting NPD relationships develop when faced with the level of novelty, on the one hand, and with the embeddedness of the NP in the customer's business environment, on the other hand. According to Bonner, customer interactivity is positively related to customer information quality when developing highly innovative and highly embedded products, but not when developing modifications or extensions of existing, low embedded products.

Although the general strategy of developing long-term relationships is known to enhance supplier performance, it is already proven that some customers are still more attractive partners for the supplier, comparing with others. Therefore „the selection of the cooperation partners has to be made consciously and carefully. Lead users, financially attractive customers, and close customers are attractive interaction partners.” (Gruner and Homburg, 2000, p. 11).

Based on a transaction-cost analysis (how organizations can obtain maximum utility from their relationships with other organizations), Athaide and Rochard (2009) propose for the innovative company to manage a portfolio of relationship approaches with buyers during the NPD because, from its three basic components - a bilateral approach, relying on a mutual exchange of information, a buyer-guided approach, and a seller-guided approach -, no one is always desirable. In their model, the criteria to adopt a specific approach being both buyer-related (perceived buyer knowledge and prior relationship history) and innovation-related (product customization and technological uncertainty) characteristics, on the one hand, and behavioural dimensions (product co-development, pre-installation product knowledge generation, buyer education, installation support and post-installation product knowledge generation), on the other hand, the performance to be finally evaluated will be the overall innovator's relationship satisfaction.

\section{Relationship marketing along the NPD process}

The process of co-innovation borrows from the NPD process descriptions of the multi-stages frameworks (Fang et al., 2008; Alam, 2005 and 2002), with the classic phases of idea generation and screening, concept development and testing, marketing strategy development, business analysis, product development, test marketing and commercialization.

Customer involvement at certain stages of co-innovation is more beneficial than at others. Regarding the distribution of RM along the stages of the NPD process, in both the breadth and the degree of involvement, researchers are divided. Traditionally, customer involvement has been suggested to be beneficial firstly in the initial ideation - and final stages - testing (Gruner and Homburg, 2000; Enkel et al., 2005; Lagrosen, 2005; Urban and von Hippel, 1988). This invites the possibility that the customers' opinions will be lost or at least diluted during the intermediate stages of the process (Campbell et al., 2007).

Lagrosen (2005) suggests that the emphasis should be in early stages of the process for the transactional customer relationsships, in the early and in the testing stage and occasionally only in other stages for the facilitative customer relationships, and a longitudinal one, in all stages for the integrative customer relationships. New studies sustain more and more the last approach, in which companies seek to engage customers to innovate throughout the entire innovation process (Carbonell et al., 2009). In this respect, Stump at al. (2002) tray to offer even a decision guide for managers to help them deciding where and how much to engage interactions with buyers in different stages of the NPD process. 
Regarding the new service performance, the impact of customers involvement is independent of the stage of the development process, despite the different roles played by them (Kuusisto and Riepula, 2011). This provides support for Cooper's (2011) advice to seek and develop customer relationships (input and feedback) at every step of the way throughout the entire development process, from beginning to end. This is found to be especially true for companies developing technologically innovative services or for situations of innovating during technological turbulences (Carbonell et al., 2009).

Based on three characteristics proposed by Diener and Piller (2010) - the stage in the innovation process, the degree of collaboration, and the degrees of freedom for the tasks assigned to customers -, Piller et al. (2011) describe eight ideal types of co-creation with customers, as follows: idea contests, idea screening through customers, product-related discussion forums, and communities of creation for idea generation, at the front end of the innovation process, and toolkits for user innovation, toolkits for customer co-design by configuration in mass-customization settings, virtual concept testing/trading, and communities of creation for problem solving, as network or community-based cocreation, at the back end of the innovation process (p. 11-15).

Related to the distribution of RM along the stages of the NPD process, Lehtimaki (2012) proposes a typology of co-innovation processes according to the breadth and depth of customer involvement: a customized (solution) selling-type, which involve the customer more or less throughout the co-innovation process, but not deeply, a testing focused type aiming to receive information and feedback from the customers, and a truly cooperative type meaning an intensive cooperation between the involved parties throughout the NPD process. Lynch and O'Toole (2010) also describe the dynamics of the interaction atmosphere of a dyadic NPD project, with two levels of the analysis - the change in the interaction atmosphere and the identification of the process dynamics that most impact in the studied case. All of this can be used in other settings to handle the NPD interaction atmosphere by collaborating parties (p. 126).

New capabilities for rapid and inexpensive customer interactions to all stages of the NPD process comes today from ICT tools, that allow web-based methods like information pump, fast polyhedral adaptive conjoint estimation, interactive webbased conjoint analysis, virtual concept testing on the web, securities trading of concepts a.s.o. (Dahan and Hauser, 2002). This way, customers are enabeled to learn their own preferences and, in the same time, the NPD team to understand complex feature interactions of the virtual products designed by customers.

\section{Conclusions}

Because, in the future, organizations will be more and more differentiated by their capability to successfully interact with their stakeholders, customers first, it will be valuable to analyse if companies really involve them in their new product development (NPD) process, how do they do this and what results it produces. There is a growing body of literature that deals with innovation and RM.

As overwhelmingly demonstrated, the most successful innovation and NPD efforts match a set o fully understood customer problems to a cost-competitive solution to those problems (Griffin et al., 2012; Rust et al., 2009). More and more these days, the stakeholders are attracted in the design process, where marketing and R\&D are fully integrated. During the NPD process, a complex set of relationship approaches develop between producer and stakeholders, especially the customers. Because understanding customer needs driving product innovation is vital for NP developers, it is important for them to identify that dimensions of the relationship process able to make the organization more proactive. 


\section{References}

Agaryia, A.K., Singh, D. (2011), What Really Defines Relationship Marketing? A Review of Definitions and General and Sector-Specific Defining Constructs, Journal of Relationship Marketing, vol. 10, no. 4, pp. 203-237.

Alam, I. (2005), Interacting with Customers in the New Product Development Process, in Kahn, K.B. (edit.), The PDMA handbook of new product development, $2^{\text {nd }}$ Edition, Hoboken, NJ, Editura John Wiley \& Sons, Inc.

Alam, I. (2002), An exploratory investigation of user involvement in new service development, Journal of Academy of Marketing Science, vol. 30, no. 3, pp. 250-261.

Anderson, J.C., Haskansson, H., Johanson, I. (1994), Dyadic business relationships within a business network context, Journal of Marketing, no. 58, 1994, pp. 115.

Athaide, G.A., Rochard R.K. (2009), Managing Seller-Buyer Relationships during New Product Development, Journal of Product Innovation Management, no. 26, pp. 566-577.

Athanassopoulos, D.A. (2000), Customer satisfaction cues to support market segmentation and explain switching behaviour, Journal of Business Research, Vol. 47, pp. 191-207.

Bhalla, G. (2011), Collaboration and Co-creation: New Platforms for Marketing and Innovation, Springer Science+Business Media, LLC.

Bonner, J.M. (2010), Customer interactivity and new product performance: Moderating effects of product newness and product embeddedness, Industrial Marketing Management, vol. 39, no. 3, pp. 485-493.

Campbell, R.I., De Beer, D.J., Barnard, L.J., Booysen, G.J., Truscott, M., Cain, R., Burton, M.J., Gyi, D.E., Hague, R. (2007), Design evolution through customer interaction with functional prototypes, Journal of Engineering Design, vol. 18, no. 6, pp. 617-635.

Carbonell, P., Rodríguez-Escudero, A.I., Pujari, D. (2009), Customer Involvement in New Service Development: An Examination of Antecedents and Outcomes, Journal of Product Innovation Management, vol. 26, no. 5, pp. 536-550.

Chesbrough, H.W. (2011), Open Services Innovation: Rethinking Your Business to Grow and Compete in a New Era, Jossey-Bass, San Francisco, CA.

Chesbrough, H.W. (2008), Open innovation: A new paradigm for understanding industrial innovation, in Chesbrough, H.W., Vanhaverbeke, W., West, J. (edit.), Open Innonation: Researching a New Paradigm, Oxford University Press, New York, NY.

Cooper, R.G. (2011), Winning at New Products: Creating Value Through Innovation, $4^{\text {th }}$ Edition, Basic Books, New York, NY.

Dahan, E., Hauser., J.R. (2002), The Virtual Customer, Journal of Product Innovation Management, no. 19, pp. 332-353.

Diener, K., Piller, F.T. (2010), The Market for Open Innovation. The 2010 Open Innovation Accelerator Study, Technology and Innovation Management Group, Aachen University, School of Business and Economics, Aachen.

Eisenhardt, K., Galunic, D. C. (2000), Coevolving: At Last, a Way to Make Synergies Work, Harvard Business Review, vol. 78, no. 1, pp. 91-100.

Enkel, E., Kausch, C., Gassmann O. (2005), Managing the Risk of Customer Integration, European Management Journal, vol. 23, no. 2, pp. 203-213.

Evans, P., Wolf, B. (2005), Collaboration Rules, Harvard Business Review, vol. 83, no. 7, pp. 96-104.

Fang, E., Palmatier, R.W., Evans, K.R. (2008), Influence of customer participation on creating and sharing of new product value, Journal of the Academy of Marketing Science, no. 36, pp. 322-336. 
Franke, N. (2006), Finding Commercially Attractive User Innovations: A Test of Lead-User Theory, Journal of Product Innovation Management, vol. 23, no. 4, pp. 301-315.

Griffin, A., Price, R., Vojak, B. (2012), Serial Innovators: How Individuals Create and Deliver Breakthrough Innovations in Mature Firms, Stanford University Press, Stanford Business Books, Stanford, CA.

Gruner, K.E., Homburg, C. (2000), Does Customer Interaction Enhance New Product Success?, Journal of Business Research, no. 49, pp. 1-14.

Gummesson, E. (2008), Total Relationship Marketing: Marketing management, relationship strategy, CRM, and a new dominant logic for the value-creating network economy, $3^{\text {rd }}$ Edition, Butterworth-Heinemann, Burlington.

Hansen, M.T., Birkinshaw, J. (2007), The Innovation Value Chain, Harvard Business Review, pp. 121-130.

Heide, J.B., John, G. (1990), Alliances in Industrial Purchasing: The Determinants of Joint Action in Buyer-Supplier Relationships, Journal of Marketing Research, no. 27, pp. 24-36.

Holmlund, M.(2004), Analyzing business relationships and distinguishing different interaction levels, Industrial Marketing Management, no. 33, pp. 279-287.

Hult, G.T., Mena, J.A., Ferrell, O.C., Ferrell, L. (2011), Stakeholder marketing: a definition and conceptual framework, Academy of Marketing Science Review, no. 1, pp. 44-65.

Kim, C., Mauborgne, R. (2004), Blue Ocean Strategy, Harvard Business School Publishing Co., Boston, MA.

Kuusisto, A., Riepula, M. (2011), Customer interaction in service innovation: seldom intensive but often decisive. Case studies in three business service sectors, International Journal of Technology Management, vol. 55, no. 1/2, pp. 171186.

Lagrosen, S. (2005), Customer involvement in new product development: A relationship marketing perspective, European Journal of Innovation Management, vol. 8, no. 4, pp. 424-436.

Lynch, P., O’Toole, T. (2010), A Critical Episode Analysis of the Dynamics of the Interaction Atmosphere in a New Product Development Relationship, The Industrial Marketing and Purchasing Journal, vol. 4, no. 2, pp. 106-130.

Perks, H., Moxey, S. (2011), Market-facing innovation networks: How lead firms partition tasks, share resources and develop capabilities, Industrial Marketing Management, vol. 40, no. 8, pp. 1224-1237.

Piller, F., Ihl, C., Vossen, A. (2011), Customer Co-Creation: Open Innovation with Customers, in Wittke, W., Hanekop, H (Edit.), New Forms of Collaborative Innovation and Production on the Internet. An Interdisciplinary Perspective, Universitätsverlag Göttingen, pp. 31-62.

Ramani, G., Kumar, V. (2008), Interaction Orientation and Firm Performance, Journal of Marketing, vol. 72, no. 1, pp. 27-45.

Richards, K.A., Jones, E. (2008), Customer relationship management: Finding value drivers, Industrial Marketing Management, no. 37, pp. 120-130.

Rust, R.T., Moorman, C., Bhalla, G. (2009), Rethinking Marketing, Harvard Business Review, vol. 88, no. 1, pp. 94-101.

Sabri, H. (2003), CRM: The power of prediction, Intelligent Enterprise, vol. 6, no. 12, pp. 32-35.

Sheth, J. N., Sharma, A. (2001), Efficacy of financial measures of marketing: It depends on markets and marketing strategies, Journal of Targeting, Measurement and Analysis for Marketing, vol. 9, no. 4, pp. 341-356. 
Sheth, J.N., Sisodia, R., Sharma (2000), A., The antecedents and consequences of customer-centric marketing, Journal of the Academy of Marketing Science, no. 28, pp. 55-56.

Spekman, R.E., Carraway, R. (2006), Making the transition to collaborative buyerseller relationships: An emerging framework, Industrial Marketing Management, vol. 35, no. 1, pp. 10-19.

Sun, H., Yau, H.K., MingSuen, E.K. (2010), The Simultaneous Impact of Supplier and Customer Involvement on New Product Performance, Journal of Technology Management \& Innovation, vol. 5, no. 4, pp. 70-82.

Tanner, J.F., Ahearne, M., Leigh, T.W., Mason, C.H., Moncrief, W. (2005), CRM in sales-intensive organizations: A review and future directions, Journal of Personal Selling and Sales Management, vol. 25, no. 2, pp. 171-182.

Thomas, J.S., Blattberg, R.C., Fox, E.J. (2004), Recapturing lost customers, Journal of Marketing Research, vol. XLI , pp. 31-45.

Thomas, J.S., Reinartz,W., Kumar, V. (2004), Getting the most out of all of your customers, Harvard Business Review, pp. 116-123.

Tuli, K.R., Kohli, A.K., Bharadwaj, S.G. (2007), Rethinking Customer Solutions: From Product Bundles to Relational Processes, Journal of Marketing, vol. 71, no. 3, pp. 1-17.

Urban, G.L., von Hippel, E. (1988), Lead User Analyses for the Development of New Industrial Products, Management Science, vol. 34, no. 5, pp. 569-582.

Verhoef, P.C. (2003), Understanding the effect of customer relationship management efforts on customer retention and customer share development, Journal of Marketing, no. 67, pp. 30-45.

von Hippel, E. (2005), Democratizing innovation, The MIT Press, Cambridge, MA.

Winer, R.S. (2001), A framework for customer relationship management, California Management Review, vol. 43, no. 4, pp. 89-105.

Zikmund, W.G., McLeod Jr., R., Gilbert, F.W. (2002), Customer relationship management: Integrating marketing strategy and information technology, John Wiley \& Sons, Hoboken, NJ. 